\title{
Development of a Rotatable Skull Holder "Rotacraniophor I"
}

\author{
Kazutaka ADACHI ${ }^{1)}$, Fumio OHTSUKI ${ }^{2)}$ \\ and Masao HATTORI ${ }^{3)}$ \\ 1) Department of Anthropology, Faculty of Science, \\ The University of Tokyo \\ 2) Faculty of General Education, Tokyo University \\ of Agriculture and Technology \\ 3) Riken Photoelasticity Institute
}

\begin{abstract}
In craniometry skulls have been digitized by measuring with traditional instruments. These measuring instruments require too much time and labor, when measuring a large number of skulls. We have been studying secular changes in Japanese skulls with the technique of Fourier analysis. For this study, we must digitize the contours of many skulls in Norma frontalis, Norma occipitalis, Norma lateralis, Norma verticalis and Norma basilaris. The rotatable skull holder "Rotacraniophor I" which we developed here makes it possible to fix the skulls at the standardized directions mentioned above much more quickly and easily owing to its rotatable function when photographing. This holder is constructed with a turntable, two standing poles which hold a skull at both auditory pores and two units which indicate the Orbitale. These poles and units can be precisely slided on the rails and fixed at any position. In order to examine the precision of fixation of a skull in the partial different conditions of this apparatus we measured some landmarks on five different skulls. The standard error of their threedimensional coordinates was in total within $\pm 0.74 \mathrm{~mm}$ in the $x, y, z$ directions.
\end{abstract}

Keywords Craniometry, Photogrammetry, Fourier analysis, Skull-holding instrument, Rotacraniophor I

\section{General Remarks}

In craniometry skulls are measured morphologically by using many different methods with special instruments. These methods are described in the latest edition of
MARTIN's textbook for Anthropology (MARTIN and KNUSSMANN, 1988, "Anthropologie", Chapter II: Methoden der Morphologie und ihrer Hilfswissenschaften, Paragraph A: Anthropometrie).

LESTREL established a form-analyzing 

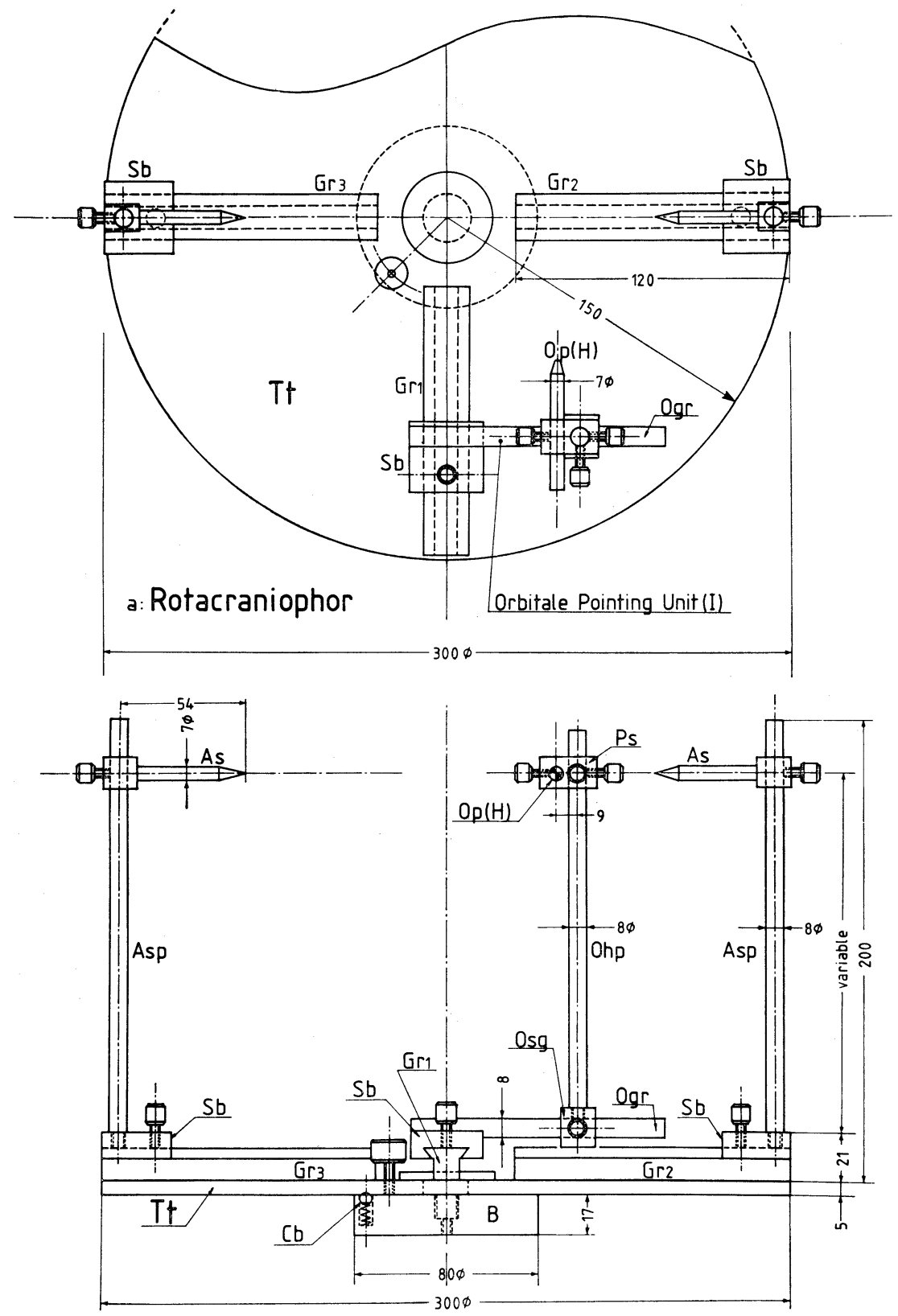

Fig. 1. The plan of Rotacraniophor I without the Orbitale pointing unit (II). The names of each component are represented with abbreviations (see Table 1). The Orbitale pointing unit (II) is shown in Fig. 2. 


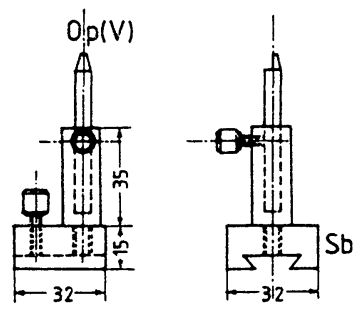

b: Orbitale Pointing Unit(II)

Fig. 2. The plan of the Orbitale pointing unit (II). The Orbitale pointer $[\mathrm{Op}(\mathrm{V})]$ can be fixed at any projected length with the thumb screw.

method applied with a technique of Fourier analysis (LESTREL, 1974; LESTREL and BROWN, 1976; LESTREL and Roche, 1976; LESTREL, 1978). We have been studying secular changes in the Japanese skull with this method. For this study we must obtain continuous $x-y$ coordinate data of twodimensional skull contours. We chose skull contours in Norma frontalis, Norma occipitalis, Norma lateralis, Norma verticalis and Norma basilaris.

The Dioptrograph is ordinarily used to draw a contour (MARTIN and KNUSSMANN, op. cit. Chapter II, Paragraph E; pp. 621622). We must pay attention to the difference between a contour which is drawn by the Dioptrograph and one drawn by the Diagraph with the Cubuscraniophor (MARTIN and Knussmann, op. cit. p. 621). The former is a contour of a projected figure of a skull and the latter is a contour of a cross section of a skull. We analyze the data of the former. But the Dioptrograph has many disadvantages, when one has a large number of skulls. So we adopted a method using photogrammetry. Notabilia for photogrammetry are described in detail in the above-mentioned textbook (MARTIN and KNussmann, op. cit. pp. 328-345, pp.
631-641). TAKAYAma (1980) established a concrete photogrammetrical method for craniology. Basically, we use his method. In this method a skull must be fixed in a certain standardized position, in the most cases its standard plane is the Frankfort Horizontal. A skull is usually fixed in the Cubuscraniophor (KIMURA and IWAMOTO, 1968; KIMURA and IWAMOTO, 1969; KIMURA et al., 1971; YASUI, 1986). But the fixation of a skull to the Cubuscraniophor is not so easy. Once when we took pictures of skulls for a previous study, we had to take much time setting skulls in standardized positions in the Cubuscraniophor. A skull is photographed from at least the five directions mentioned above. We had to take care to position it precisely before taking each photograph.

The skull holder which we have developed here reduces these problems in positioning the skulls. This rotatable skull holder "Rotacraniophor I" determines the two standardized planes, that is, the Frankfort Horizontal and the mediansagittal plane. The Frankfort Horizontal is a plane passing through three points of the right and left Porion and the left Orbitale. Our horizontal is determined with the upper ridge of both aural supporting rods [As] and the upper ridge of the Orbitale pointer $[\mathrm{Op}(\mathrm{H})]$, when a skull is held horizontally. In this case the Porion is located ca. 0 to $3 \mathrm{~mm}$ above the upper ridge of the aural supporting rod. With this reason our horizontal is the quasi Frankfort Horizontal. When a skull is held vertically, the Porion comes ca. 0 to $3 \mathrm{~mm}$ anterior to the frontal ridge of the aural supporting rod. On the other hand we define the mediansagittal plane in our case as a plane passing through the Nasion and is perpendicular to a line which connects 
the center of the both external auditory pores. Thus this line means the axis of the aural supporting rods.

\section{The Construction of the Apparatus}

The plan of Rotacraniophor I is shown in Fig. 1. A skull is held with three supporting rods at the both external auditory meatuses and the inferior edge of the orbit. This supporting method was described by Mollison (Mollison, 1938) for the first time. The components of the Rotacraniophor are mainly made of brass and a black baking finish is applied. Its Orbitale pointing unit (II) is shown in Fig. 2. A bird'seye view of the disassembled Rotacraniophor is shown in Fig. 3 and the assembled unit is shown in Fig. 4. The Orbitale pointing unit (I) is used when a skull is held horizontally and the unit (II) is used when a skull is held vertically. (cf. Fig. 5)

In Fig. 1 the turntable [Tt] is rotatable on the base [B]. Owing to the click ball [Cb] with a coil spring, the turntable is easily fixed at every 90 degrees. The sliding bases $[\mathrm{Sb}]$ on the guide rail $\left[\mathrm{Gr}_{1-3}\right]$ are to be slid to the desired position and fixed by thumb screws. The Orbitale pointing unit (II) is ordinarily located on the $\mathrm{Gr}_{2}$.

Both of the aural supporting rods [As] are fixed opposite in a straight line at the same height. Their height is variable, but from our experience a height of ca. $17 \mathrm{~cm}$ from the turntable is the best for human crania. These rods are inserted into external auditory pores (Fig. 5). The Orbitale pointer of the Orbitale pointing unit (I) $[\mathrm{Op}(\mathrm{H})]$ is fixed horizontally at the same level as the aural supporting rods so that it takes its position at a right angle to them.

We examined the precision of fixation of a skull in the partial different conditions of
Table 1. Parts list of Rotacraniophor I. Letters in brackets correspond to the same letters in Figs. 1, 2, and 3

Basement :

Turntable [Tt]

Guide rail $1\left[\mathrm{Gr}_{1}\right]$

Guide rail $2\left[\mathrm{Gr}_{2}\right]$

Guide rail $3\left[\mathrm{Gr}_{3}\right]$

Base [B]

Click ball $[\mathrm{Cb}]$

Coil spring

Thumb screw

Aural supporting unit (one pair):

Aural supporting rod [As]

Aural supporting pole [Asp]

Sliding base $[\mathrm{Sb}]$

Thumb screw

Orbitale pointing unit (I) :

Orbitale pointer $[\mathrm{Op}(\mathrm{H})]$

Pointer supporter [Ps]

Orbitale pointer holding pole [Ohp]

Orbitale pointer supporting glider [Osg]

Orbitale pointing unit guide $\operatorname{rod}[\mathrm{Ogr}]$

Sliding base $[\mathrm{Sb}]$

Thumb screw

Orbitale pointing unit (II) :

Orbitale pointer $[\mathrm{Op}(\mathrm{V})]$

Sliding base [Sb]

Thumb screw

this apparatus using a threedimensional digitizer (VECTORON: made by Kosaka Laboratory. Its nominal precision of measurement in the partial different conditions is $\pm 0.2 \mathrm{~mm}$ ). The Rotacraniophor was put on this measuring system. A skull was fixed to the Rotacraniophor and the threedimensional coordinates of the Nasion, Bregma, Inion, Asterion (right and left) and Zygomaxillare (right and left) were measured. Then the skull was turned to the five directions mentioned above and the same points were measured repeatedlly in the each direction. The skull was removed and the 


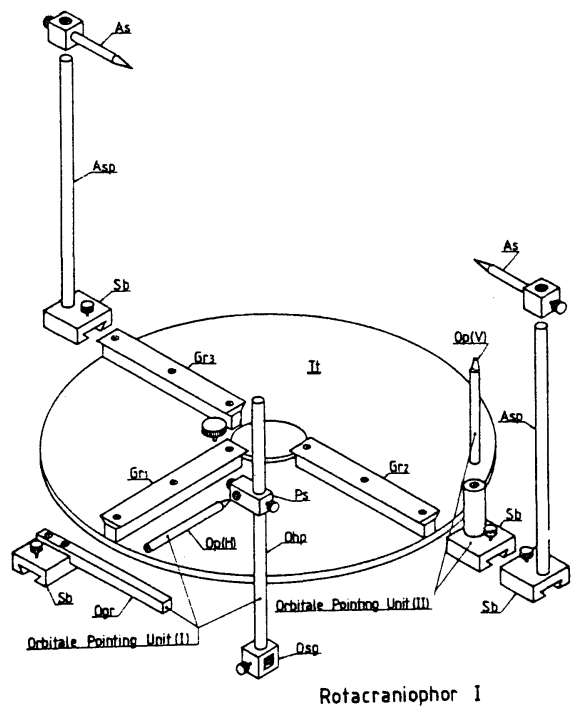

Fig. 3. A bird's eye view of disassembled Rotacraniophor I. Names of each component are indicated by the same letters as in Figs. 1 and 2 .

Table 2. Instruments which are necessary for photogrammetrical photographing

Rotacraniophor I

Reflex camera (e.g. Nikon F2)

$800 \mathrm{~m}$ telephoto lens (e.g. Nikkor ED $800 \mathrm{~mm}$ )

Electronic flashlights (e.g. National PE-321SW) $\times 3$

\section{Release cable}

Tripods (e.g. Velbon Mark-7 with $\mathrm{PH}-270) \times 2$

Light stands (e.g. Velbon LS-4 with PH-143)

Flashlight mount (e.g. Hama accessory shoe adapter 6956)

Slave unit (e.g. National slave unit PW-5)

3m-Synchro cable

Back screen stand

Section paper (e.g. Letraset SCREEN-TONE)

Flat board (ca. $50 \times 35 \mathrm{~cm}$ )

Rule or Anthropometer

Level

Rotacraniophor was disassembled and assembled again. Then the same skull was fixed to it again and the same landmarks were

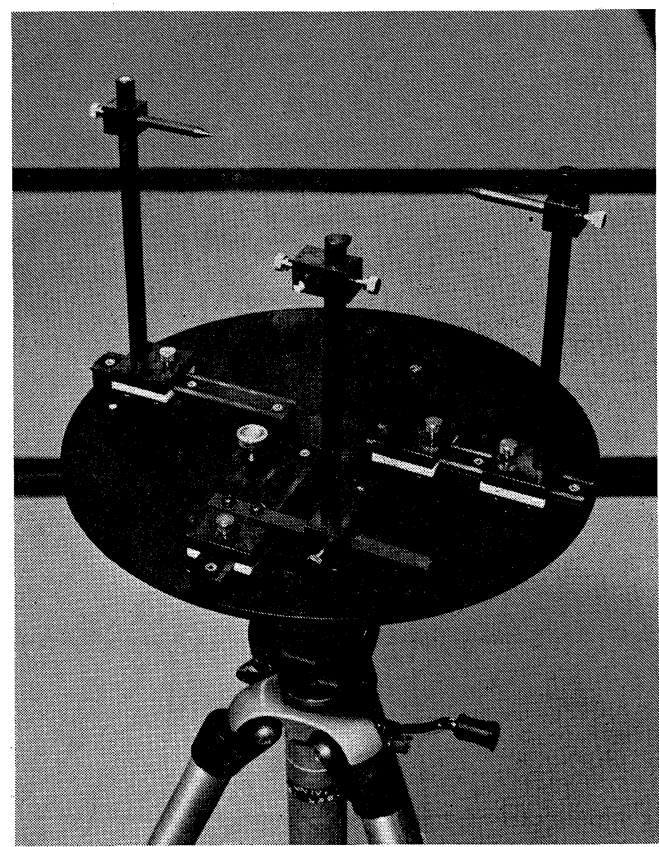

Fig. 4. A bird's eye view of assembled Rotacraniophor I on the pan head of a tripod.

measured again. We tried this routine ten times in five skulls. The results indicate the precision of fixation of a skull in the partial different conditions of this apparatus. The standard error of the three-dimensional coodinates of these landmarks was in total within $\pm 0.74 \mathrm{~mm}$ in the $x, y, z$ directions.

\section{Instructions}

1. Preparation of Rotacraniophor I

1-1. Assembly

Assemble all the parts according to Fig. 4. Set the turntable at the click position.

\section{1-2. Adjustments}

1-2-1. Slide both aural supporting units close to each other so that the pointed ends of the aural supporting rods point opposite to each other.

1-2-2. Set the Orbitale pointer of the 


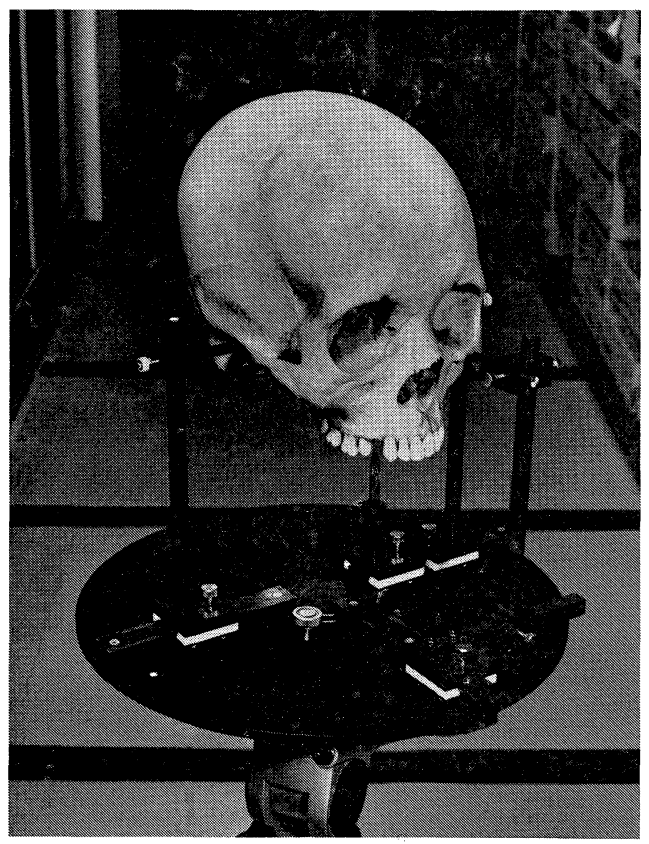

Fig. 5. A skull is fixed horizontally by Rotacraniophor I.

Orbitale pointing unit (I) parallel to the guide rail 1 and at the same height as both aural supporting rods

2. Preparations for photographing (cf. Fig. 6)

$2-1$. An area of $16 \times 2 \mathrm{~m}$ is necessary for photographing.

2-2. Assemble the tripod $\left[\mathrm{TP}_{2}\right]$ at a height of ca. $110 \mathrm{~cm}$ and stand it in a desirable position.

2-3. Place Rotacraniophor I [RC] on the pan head of the tripod.

2-4. Set Rotacraniophor I horizontally with a level

$2-5$. Set the back screen stand [BS].

2-6. Measure the exact height of the center axis of the aural supporting rod from the floor $\left[h_{2}\right]$ with a rule.

$2-7$. Assemble the other tripod $\left[\mathrm{TP}_{1}\right]$ and place the camera [Ca] with an ex- tension tube [ET] and an $800 \mathrm{~mm}$ telephoto lens $[\mathrm{L}]$. The height of its optical axis from the floor $\left[h_{1}\right]$ is the same as the height of the aural supporting $\operatorname{rod}\left[\mathrm{h}_{2}\right]$ (Refer to the measuring result of 2-6). The distance between the camera and Rotacraniophor I [d] is ca. $14 \mathrm{~m}$.

$2-8$. Attach a release cable $[\mathrm{CR}]$ and an electronic flashlight $\left[\mathrm{EF}_{1}\right]$ to the camera.

2-9. Set both aural supporting units apart as in Fig. 6.

$2-10$. Turn the whole body of Rotacraniophor I with the pan head so that the center axis of the aural supporting rod points toward the camera.

$2-11$. Adjust the optical axis of the lens to the center axis of the aural supporting rod. As a result, on looking through the finder of the camera, one will see the center of the aural supporting rod come to the center of the field and both aural supporting poles ([Asp] in Fig. 3) will meet.

2-12. Set two main electronic flashlights $\left[\mathrm{EF}_{2}, \mathrm{EF}_{3}\right]$ with light stands $\left[\mathrm{LS}_{1}\right.$, $\mathrm{LS}_{2}$ ] at the same height as the optical axis of the lens and $1 \mathrm{~m}$ from the center of Rotacraniophor I $\left[l_{1}\right.$, $1_{2}$. The incident angle of the lights $\left[\theta_{1}, \theta_{2}\right]$ is ca. 45 degrees.

2-13. Attach these two flashlights to the slave unit [SU] with a synchro cable [SC]. The sensor of the slave unit faces toward the camera. When the flashlight on the camera flashes, the two main flashlights flash at the same time.

2-14. Set the F-stop of the lens according to the film speed and guide number of the main flashlights. 

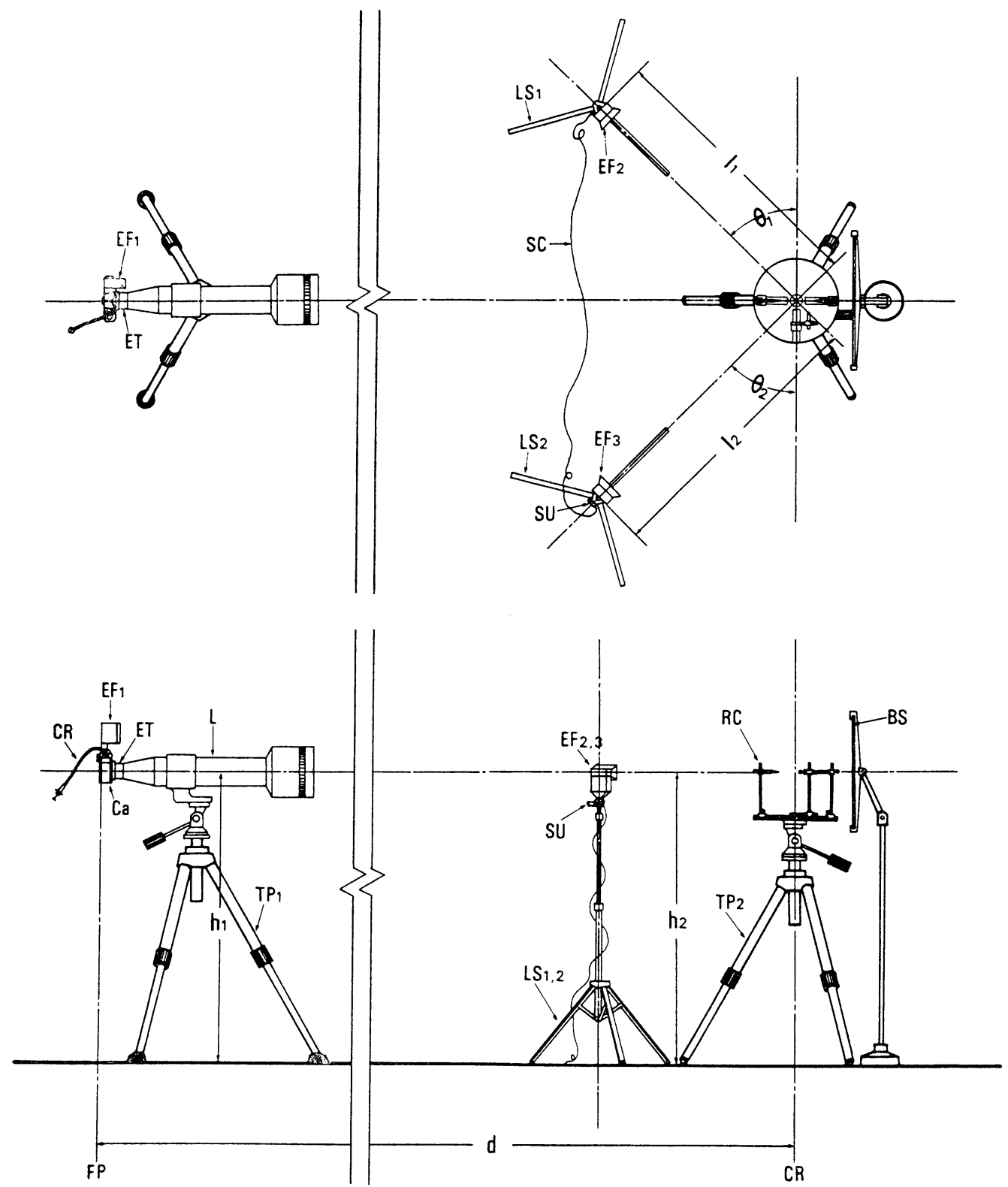

Fig. 6. Arrangement of instruments necessary for photogrammetrical photographing. See text for the explanation of the letters.

3. Calibration

3-1. A section paper attached to a flat board is used. Stand this board vertically in the center of the Rota- craniophor I facing toward the camera so that the optical axis of the lens crosses it perpendicularly (Fig. 7). 


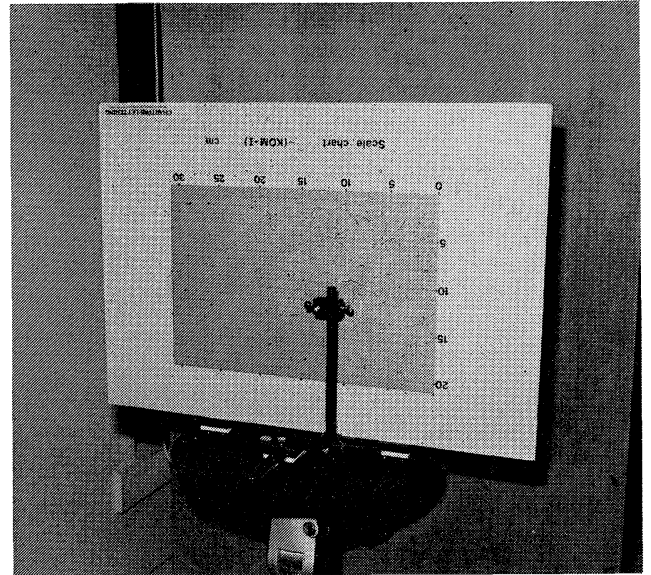

Fig. 7. Photographing of a section paper on a flat board for the calibration. This board is stood vertically at the center of Rotacraniophor I. The optical axis of the lens crosses perpendicularly with this board. In order to photograph the whole of the section paper, the board is stood upside down.

3-2. Photograph this section paper. This frame is used as a scale for printing.

3-3. Remove the board.

4. Skull setting

4-1. Set a skull horizontally so that the center axis of Rotacraniophor I goes through its mediansagittal plane. The upper ridge of the Orbitale pointer of the Orbitale pointing unit (I) points at the left Orbitale. The Frankfort Horizontal is formed with the upper ridge of the Orbitale pointer of the Orbitale pointing unit (I) and the upper ridge of both aural supporting rods in this case.

4-2. Photograph the skull in the direction of Norma frontalis.

4-3. Rotate the Rotacraniophor I clockwise 90 degrees to the next click stop. Point the Nasion with a needle (Fig. 8).

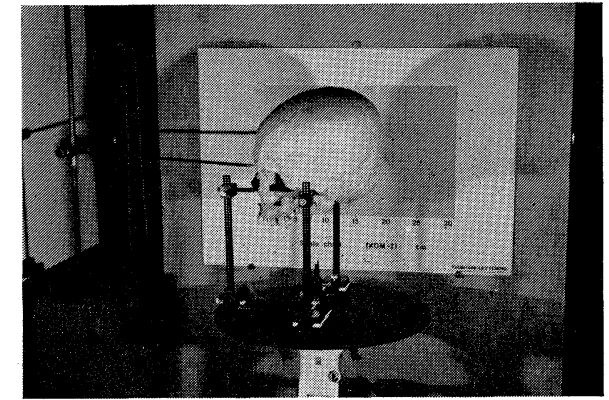

Fig. 8. A scene from one of our photographs in the direction of Norma lateralis. A needle indicates the position of Nasion. The section paper is used as a back screen in our case.

4-4. Photograph the skull in the direction of Norma lateralis.

4-5. Rotate the Rotacraniophor I clockwise 90 degrees to the next click stop.

4-6. Photograph the skull in the direction of Norma occipitalis.

4-7. Turn the turntable 180 degrees to the Norma frontalis position.

4-8. Remove the Orbitale pointing unit (I). Rotate the skull so that the face comes to the bottom. Support the Orbitale with the Orbitale pointer of the Orbitale pointing unit (II). Fix this pointer with its thumb screw.

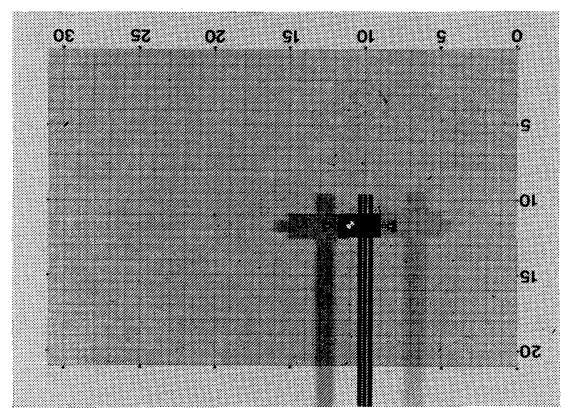

Fig. 9. Printed section paper which was photographed in Fig. 7. In order to photograph all of the section paper, it was stood upside down (This plate is ca. $3 / 20$ of the original size). 


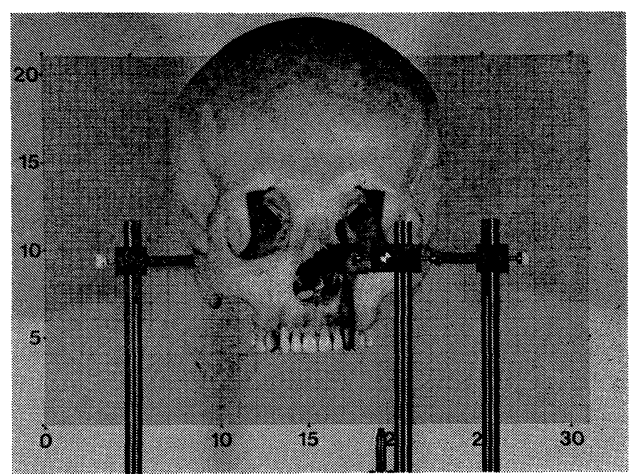

a

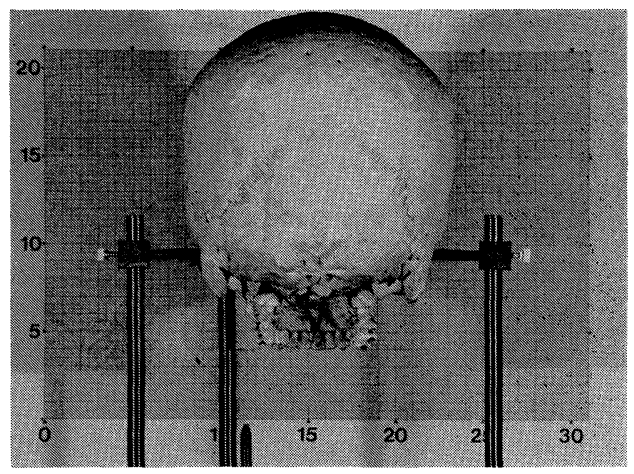

C

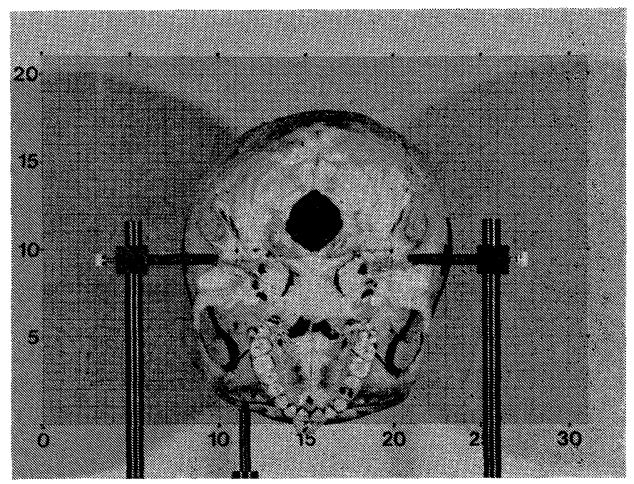

e

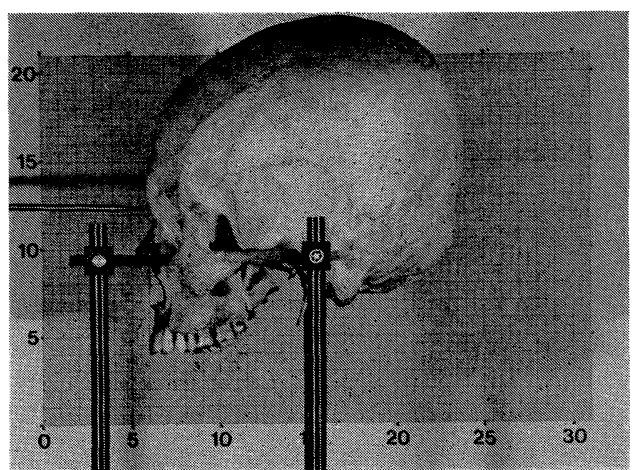

b

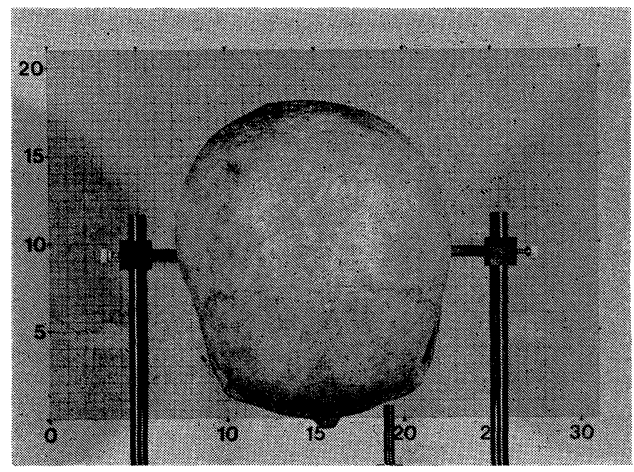

d

Fig. 10. An example of a photographed and printed skull in the direction of Norma frontalis (a), Norma lateralis (b), Norma occipitalis (c), Norma verticalis (d) and Norma basilaris (e). [Note: The section paper in the background was used merely as a back screen and does not indicate the actual size. The size of the back-paper scale is just a bit smaller than the real size.] 
In this case the frontal ridge of this pointer points at the left Orbitale of the skull. The Frankfort Horizontal is formed with the frontal ridge of the Orbitale pointer of the Orbitale pointing unit (II) and the frontal ridge of both aural supporting rods in this case.

4-9. Photograph the skull in the direction of Norma verticalis.

4-10. Turn the turntable 180 degrees.

4-11. Photograph the skull in the direction of Norma basilaris.

5. Film development and printing

5-1. Develop the film with the normal procedure.

5-2. Use polyethylene laminated photographic paper (size: $8 \times 10$ inches) in order to avoid distortion through processing.

5-3. Project the section paper which was taken at 3-2 with an enlarger and adjust it to the original size (Fig. 9).

5-4. Begin the printing of skulls.

Printed skull examples from five directions are shown in Fig. 10.

\section{Example of Application}

An example of our experiment is shown in Fig. 11. In order to digitize two-dimensional figures, we used a magnetostrictive digitizer (e.g. Bit Pad One or Mitablet*).

* Contact addresses. Bit Pad One: Summagraphics Corporation, 35 Brentwood Avenue, Fairfield Connecticut 06430, USA. Mitable'T: Grapitec, Mita 43 Mori Building, 3-13-16, Mita, Minato-ku, Tokyo 108, Japan.
Applications and instructions for a digitizer are described by TAKAHASHI and ADACHI (1982, 1983).

\section{抄録}

回転式頭骨固定台 “Rotacraniophor I” の開発

足立和隆・大槻文夫・服部昆男

著者らは，頭蓋の投影輪郭をフーリエ解析すること によって，日本人頭蓋形態の時代差を検討してきた。 頭蓋の対象となる投影輪郭は, 正面観 (Norma frontalis), 後面観 (Norma occipitalis), 側面観 (Norma lateralis), 上面観 (Norma verticalis), 底 面倠見（Norma basilaris）の5通りである。これらの 輪郭を得るためには，古典的な方法として Dioptrograph を利用することが考学られるが，この方法は 手閏と時開が非常にかかる。一方，高山は， $35 \mathrm{~mm}$ カメラで焦点距離 $800 \mathrm{~mm}$ 以上の超望遠レンズを用 いれば，写真計測によっても高い精度で頭骨の輪郭が 得られることを示した（高山，1980）。著者らも基本 的にはこの方法にしたがって頭骨の撮影を行なった が，当初，頭骨を上就の 5 通りの位置に正確に固定す るためにかなりの労力と侍間を要した。そこで，本報 告に縚介するよ弓な, 回転式頭骨固定台 (Rotacraniophor I) を製俳し，利用したところ，ひとつの 頭骨において上記 5 通りの撮影を行ならのに要する洔 間をかなり短縮することができた。この固定台は回転 可能な円盤の上に左右の耳孔を支觉るための支柱 [aural supporting unit] が各 1 本, そして頭骨が水 平の場合に眼简下縁を支えるための支柱 [Orbitale pointing unit (I)]が 1 本, さらに頭骨が垂直の場合 凤腿筑下縁を支える部品 [Orbitale pointing unit(II)] が立った構造をしている。これらの支柱はレールの上 を垂直な状態でスライドさせ，任意の位置で固定でき るようになっている。耳孔にさしこむ支持棒（aural supporting rod) 拈よび眼简指示棒 (Orbitale pointer) の高さも仕:意にかえられるが，一般的な頭骨を固定す る場命, 耳眼水平面が円盤の上, 約 $17 \mathrm{~cm}$ の位置に

Fig. 11. A printed skull in Norma lateralis (top) and its digitized contour (bottom). The contour is traced by a digitizer and drawn by a plotter. The angle between each radiated line is 5 degrees. The $\mathrm{x}-\mathrm{y}$ coordinates of the contour will be calculated with a Fourier method. [n: Nasion, or: Orbitale, po: Porion, FH: Frankfort Horizontal, vc: vector center, spp: the point where the line Nasion-Porion crosses the contour at the occipital area.] 

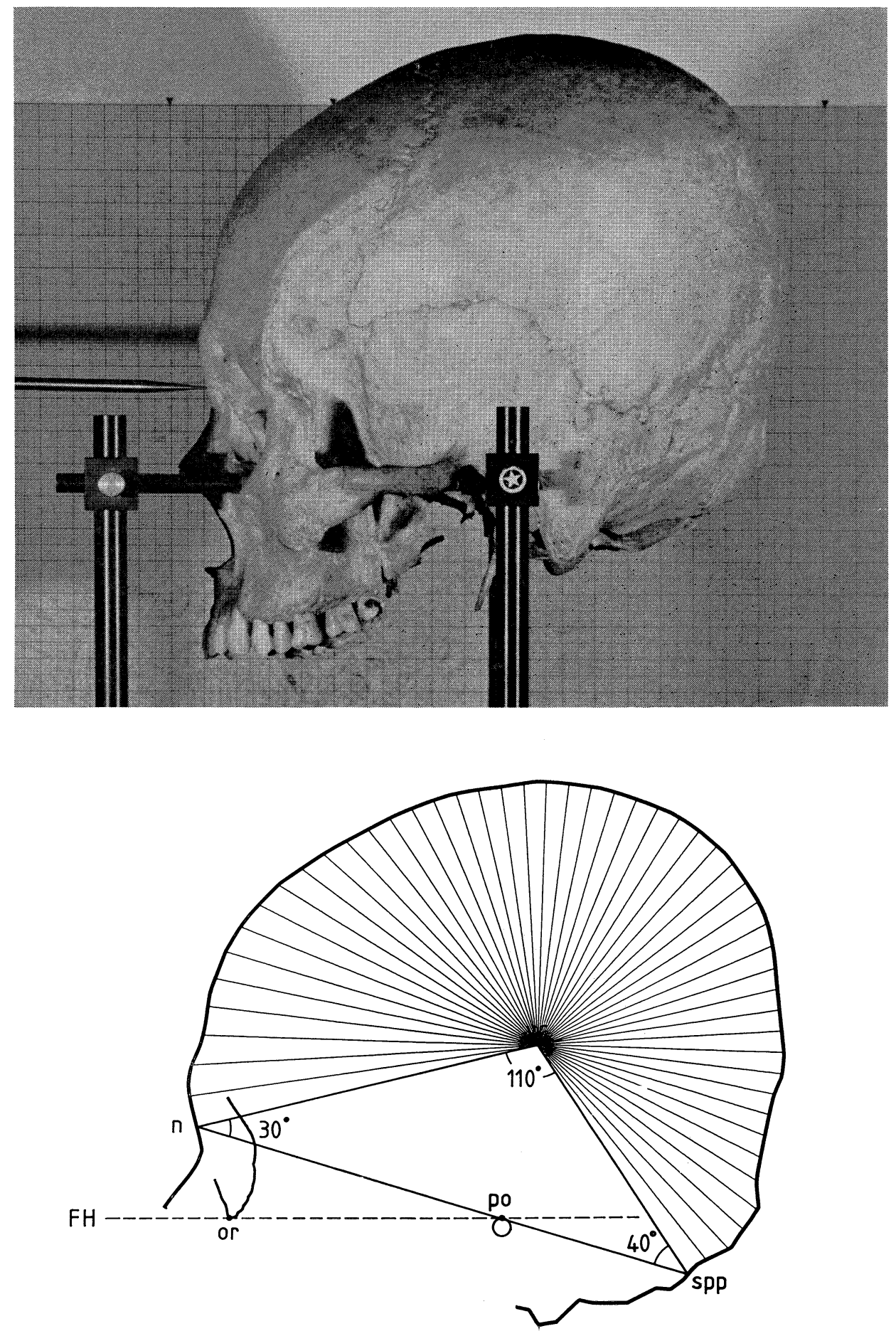
くるよ5にこられを固定するとよい。写真撮影にあた っては, 頭骨固定台の円艋の回転軸と左右の年孔にさ しこむ支持棒 (aural supporting rod) の中心軸との 交点を撮影レンズの光軸が通るように网機材を設置す る。頭骨の固定の際にはまず頭骨をカメラのほ5に问 け，耳孔を支える支柱を左右にスライドさせてナジオ ンが夙画面中央にくるようにする。ここでは，正中欠 状面をナジオンを通り，左右の耳孔にさしこむ支持棒 の中心軸に垂直な平面と定孚する。Orbitale pointing unit (I) で頭骨を水平に固定したら，问盤を回転させ ることによって, 正面観, 側面観, 後洎観の撮影を行

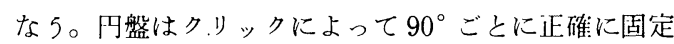
される。次に Orbitale pointing unit (I) をはずし, 頭骨を前に回転させて腿䠛下縁を Orbitale pointing unit（II）で支える。この状態で上面観，そして船 を $180^{\circ}$ 回転させて底面镍の撮影を行な5。撮影され た頭骨は, ポリエチレンコートされた寸法精度の高い 印面紙に正確に原寸大に焼き付けられ，これらの画像 中から頭蓋の輪郭の來標を、ディジタイザーを利用し てオンラインでパーソナルコンピュータに入力した。

\section{References}

Kimura, K. and S. Iwamoto, 1968: Photometric studies of the location of some measuring points at the lateral view of the Japanese skulls. Bull Fac. Phys. Ed., Tokyo Univ. of Ed., 7: 69-78. (In Japanese)

[本村邦彦・岩本壮太郎，1968：頭蓋側面観の写真 計測学的研究, 東京教育大学体育学部紀要, $7: 69$ 78.]

KimURA, K. and S. Iwamoto, 1969: Photometric studies of the secular change of the lateral view in the Japanese skulls. Bull. Fac. Phys. Ed., Tokyo Univ. of Ed., 8: 133-140. (In Japanese)

[木村邦彦・岩本壮太郎，1968：日本人頭蓋側面観 の時代変化の写真計測学的研究, 東京教育大学体育 学部紀要, 8:133-140.]

Kimura, K., A. Takahashi and S. Inamoto, 1971: Photometric studies on the sex difference of the modern Japanese skull. Bull. Fac. Phys. Ed., Tokyo Univ. of Ed., 10:77-86. (In Japanese)

[木村邦彦・高橋 叔・岩本壮太郎, 1971：頭蓋側
洎観の性差, 東京教育大学休育学部紀要, 10:77 86. ]

Lestrel, P.E., 1974: Some problems in the assessment of morphological size and shape differences. Yearbook of Phys. Anthrop., 18: 140-162.

Lestrel, P.E. and D. Brown, 1976: Fourier analysis of adolescent growth of the cranial vault: A longitudinal study. Human Biol., 48: 517-528.

LesTrel, P.E. and A.F. Roche, 1976: Fourier analysis of the cranium in trisomy 21. Growth, 40: 385-398.

Lestrel, P.E., 1978: A quantitative approach to skeletal morphology: Fourier analysis. SPIE, Applications of Human Biostereometrics (NATO), 166: 80-93.

Martin, R. und R. KNissmann, 1988: Anthropologie, Band I/1. Gustav Fischer Verlag.

Mollison, T., 1938: Spezielle Methoden anthropometrischer Messung. In: ABDERHALdEN, E. (Herausgeber): Handbuch der biologischen Arbeitsmethoden. Abt. VII: Methoden der vergleichenden morphologishen Forschung, Teil 2, Heft 3. Urban \& Schwarzenberg, Berlin.

Takahashi, H. and K. Adachi, 1982: A Program for analyzing two-dimensional forms using a digitizer. Interface, 59: 200-214. (In Japanese)

[高橋秀雄・足立和隆, 1982 ：ディジタイザによる 2 次元図形解析プログラム，インターフェース, 59: 200-214.]

Takahashi, H. and K. Adachi, 1983: A Program for calculating the geometrical properties of three-dimensional shape using a microcomputer. J. Anthrop. Soc. Nippon, 91: 401-416. (In Japanese)

[高橋秀雄・足立和隆，1983：等高線表示された 3 次元図形の特性值計算法. 人類学雑誌, 91：401416. ]

TAKayama, H., 1980: An examination of photographic measurement in craniology. J. Anthrop. Soc. Nippon, $88: 249-268$.

YASUI, K., 1986: Method for analyzing outlines with an application to recent Japanese crania. Am. J. Phys. Anthropol., 71: 39-49. 
足立和 隆東京大学理学部人類学教室

于113 東京都文京区本郷 7-3-1

Kazutaka ADACHI Department of Anthropology, Faculty of Science The University of Tokyo

7-3-1, Hongo, Bunkyo-ku, Tokyo 113, Japan 